\title{
Determinan Kepuasan Konsumen Unit Usaha Darma Wanita Persatuan UIN Syarif Hidayatullah Jakarta
}

\author{
Zuwesty Eka Putri \\ UIN Syarif Hidayatullah Jakarta \\ zuwesty_eka@uinjkt.ac.id
}

\begin{abstract}
Dharmawanita UIN Syarif Hidayatullah Jakarta is an activity forum that aims to develop the creativity, expertise of female employees and the wife of an employee of the Syarif Hidayatullah UIN Jakarta. Some activities managed by Dharmawanita are business units engaged in food and beverage providers in the canteen and catering to the academic community of UIN Syarif Hidayatullah in particular and the community in general. The purpose of this study was to obtain empirical evidence related to factors that influence customer satisfaction or customers who use products of the Dharmawanita business unit of UIN Syarif Hidayatullah Jakarta. In addition, this study also aims to analyze the factors that determine consumer purchasing decisions. The results showed that the factors that influence the level of customer satisfaction are: physical appearance, service, menu, taste, and price. Then, factors that influence consumer purchasing decisions whether inside or outside the campus environment are: menu, taste, and price.
\end{abstract}

Keywords: customer satisfaction, physical appearance, service, menu

\begin{abstract}
Abstrak
Dharmawanita Persatuan UIN Syarif Hidayatullah merupakan satu wadah aktivitas yang bertujuan untuk mengembangkan kreatifitas, keahlian pegawai wanita maupun istri pegawai UIN Syarif Hidayatullah Jakarta. Beberapa aktivitas yang dikelola oleh Dharmawanita adalah unit usaha yang bergerak dibidang penyedia makanan dan minuman di kantin maupun di katering bagi civitas akademik UIN Syarif Hidayatullah khususnya dan masyarakat pada umumnya. Tujuan penelitian ini adalah untuk mendapatkan bukti empiris terkait faktor-faktor yang mempengaruhi kepuasan konsumen atau pelanggan pengguna produk unit usaha Dharmawanita UIN Syarif Hidayatullah Jakarta. Selain itu penelitian ini bertujuan pula untuk menganalisis faktor yang menentukan keputusan pembelian konsumen. Hasil penelitian menunjukkan bahwa faktor yang memengaruhi tingkat kepuasan konsumen ialah: tampilan fisik, pelayanan, serta menu, rasa, dan harga. Kemudian, faktor yang memengaruhi keputusan pembelian konsumen apakah di dalam atau di luar lingkungan kampus ialah: menu, rasa, dan harga.

Kata Kunci: kepuasan konsumen, tampilan fisik, pelayanan, menu.
\end{abstract}

Diterima: 11 Agustus 2018; Revisi: 2018; Disetujui: 2018 


\section{PENDAHULUAN}

Badan Layanan Umum (BLU) adalah instansi di Lingkungan pemerintah yang dibentuk untuk memberikan pelayanan kepada masyarakt berupa penyedia barang dan atau jasa yang dijual tanpa mengutamakan mencari keuntungan dan dalam melakukan kegiatannya didasarkan pada prinsip efisiensi dan produktivitas. BLU bertujuan untuk meningkatkan pelayanan kepada masyarakat dalam rangka memajukan kesejahteraan umum dan mencerdaskan kehidupan bangsa dengan memberikan fleksibilitas dalam pengelolaan keuangan berdasarkan prinsip ekonomi dan produktivitas dan penerapan praktik bisnis yang sehat. Dharma Wanita Persatuan (DWP) UIN Syarif Hidayatullah Jakarta adalah organisasi isteri Pegawai Negeri Sipil (PNS) di lingkungan UIN syarif Hidayatullah Jakarta yang ditetapkan Musyawarah Nasional luar biasa Dharma Wanita pada tanggal 7 Desember 1999 dan merupakan organisasi mandiri, tidak terikat partai politik dan demokratis. Organisasi ini sangat strategis dan penting bahkan menjadi kunci dalam mendukung masa depan organisasi UIN Syarif Hidayatullah Jakarta termasuk strategi untuk mengatasi masalah yang khususnya di bidang pendidikan, kesehatan, ekonomi, sosial budaya dan lingkungan.

Konsumen dapat diartikan sebagai siapa saja yang berkepentingan dengan produk layanan yang ditawarkan oleh perusahaan. Konsumen dapat berupa individu (perorangan), pemerintah, maupun swasta. Konsumen merupakan salah satu indikator keberhasilan maju tidaknya suatu perusahaan. Namun seringkali perusahaan mengabaikan konsumen, konsumen hanya dianggap sebagai "sapi perah" dalam menghasilkan keuntungan perusahaan tanpa berupaya untuk memberikan pelayanan prima kepada mereka. Apabila hal ini berlanjut terusmenerus, maka konsumen akan meninggalkan perusahaan karena ketidakpuasan atas pelayanan perusahaan, karena konsumen saat ini sudah "pintar" dan tidak mau dibodohi lagi. Perusahaan harus menempatkan konsumen sebagai raja dalam perusahaan, sehingga setiap elemen perusahaan harus mampu memberikan pelayanan yang terbaik kepada konsumen. Persaingan bisnis saat ini semakin tajam. Konsep pemasaran telah bergeser dari product oriented menjadi customer oriented artinya : tidak hanya memperhatikan mutu/kualitas dari produk tetapi 
juga memperhatikan kepuasan konsumennya. Konsep customer oriented dapat diterapkan pada perusahaan yang menghasilkan produk dan mutlak diterapkan pada perusahaan yang bergerak dibidang jasa. Bentuk dari konsep customer oriented ini adalah perusahaan harus lebih memperhatikan konsumennya dengan cara memberikan pelayanan prima dan selalu menjalin hubungan yang baik sehingga memuaskan keinginan dan kebutuhan konsumen.

Pada umumnya perusahaan hidup dalam lingkungan yang berubah dengan cepat, dinamis dan rumit. Perusahaan harus mampu bersaing dalam menunjukkan keunggulan akan produk atau jasa yang dihasilkan dibanding kompetitornya. Apabila suatu perusahaan ritel sudah bisa mendapatkan konsumen, langkah selanjutnya adalah bagaimana agar konsumen tersebut bisa menjadi pelanggan tetapnya dan mempertahankan loyalitas konsumen untuk terus bisa berbelanja di perusahaan ritel tersebut. Tidak jauh berbeda dengan Usaha Dharma Wanita Persatuan UIN Syarif Hidayatullah Jakarta yang dituntut untuk mempertahankan konsumen atau pelanggannya, bagaimana loyalitas mereka terhadap penggunaan produk Dharma Wanita Persatuan misalnya : loyalitas terhadap pembelian makanan di Kantin Dharma Wanita Persatuan UIN Syarif Hidayatullah Jakarta.

\section{METODE}

Berdasarkan tabel penentuan sampel Isaac dan Michael dengan jumlah populasi civitas akademika di UIN Syarif Hidayatullah Jakarta baik mahasiswa, dosen dan karyawan lebih dari sepuluh ribu orang orang dan tingkat kesalahan $5 \%$, maka jumlah sampel adalah berjumlah 200 orang. Komposisi yang dipergunakan ialah: 50 persen responden berasal dari mahasiswa, 30 persen responden berasal dari dosen, dan 20 persen responden berasal dari karyawan.

Untuk menganalisis faktor-faktor yang memengaruhi kepuasan civitas akademika terhadap penyelenggaran kantin di UIN Syarif Hidayatullah Jakarta digunakan analisis empiris dengan menggunakan regresi linear berganda dengan estimator ordinary least square. Adapun persamaan model ordinary least square yang dipergunakan sebagai analisis dalam penelitian ini adalah: 


$$
Y_{i}=\alpha_{0}+\beta_{1} X_{1 i}+\beta_{2} X_{2 i}+\beta_{3} X_{3 i}+\varepsilon_{i}
$$

Dimana

$\mathrm{Y}_{\mathrm{i}}$ adalah tingkat kepuasan civitas akademika

$\mathrm{X}_{1 \mathrm{i}}$ adalah tampilan fisik

$\mathrm{X}_{2 \mathrm{i}}$ adalah pelayanan

$\mathrm{X}_{3 \mathrm{i}}$ adalah menu, rasa, dan harga

Untuk menganalisis faktor-faktor yang menentukan keputusan pembelian konsumen, apakah memutuskan untuk membeli di kantin pada lingkungan UIN Syarif Hidayatullah Jakarta atau membeli di luar lingkungan UIN Syarif Hidayatullah Jakarta akan menggunakan teknik regresi logit.

Adapun persamaan model logit yang dipergunakan sebagai analisis dalam penelitian ini adalah:

$$
Y_{i}=\alpha_{0}+\beta_{1} X_{1 i}+\beta_{2} X_{2 i}+\beta_{3} X_{3 i}+\varepsilon_{i}
$$

Dimana

$\mathrm{Y}_{\mathrm{i}}$ adalah pemilihan lokasi kantin

Dimana $\quad: 1=$ di lingkungan UIN Syarif Hidayatullah Jakarta

$$
0 \text { = di luar lingkungan UIN Syarif Hidayatullah Jakarta }
$$

$\mathrm{X}_{1 \mathrm{i}}$ adalah tampilan fisik

$\mathrm{X}_{2 \mathrm{i}}$ adalah pelayanan

$\mathrm{X}_{3 \mathrm{i}}$ adalah menu, rasa, dan harga

Untuk memperkuat temuan empiris yang didapat, maka akan dilakukan teknik analisis dengan kualitatif deskriptif. Metode analisis ini juga dipergunakan untuk memperkuat temuan pada tujuan penelitian sebelumnya. Sehingga hasil empiris kuantitatif akan menjadi hasil awal yang kemudian diperkuat dengan metode deskriptif kualitatif.

\section{HASIL DAN PEMBAHASAN}

Tabel 1. menunjukkan bahwa faktor yang memengaruhi besaran tingkat kepuasan civitas akademika UIN Syarif Hidayatullah Jakarta ialah variabel tampilan fisik, variabel pelayanan, serta variabel menu, rasa dan harga. Tampilan fisik memiliki pengaruh positif, hal ini menandakan bahwa semakin baik tampilan 
fisik dari kantin, maka akan semakin menaikkan tingkat kepuasan konsumen. Pelayanan pun memiliki pengaruh positif terhadap tingkat kepuasan, hal ini menandakan bahwa semakin baik pelayanan yang diberikan maka akan semakin tinggi pula tingkat kepuasan konsumen. Selanjutnya variabel menu, rasa, dan harga memiliki pengaruh yang positif terhadap tingkat kepuasan konsumen.

Tabel 1. Hasil Regresi Kepuasan

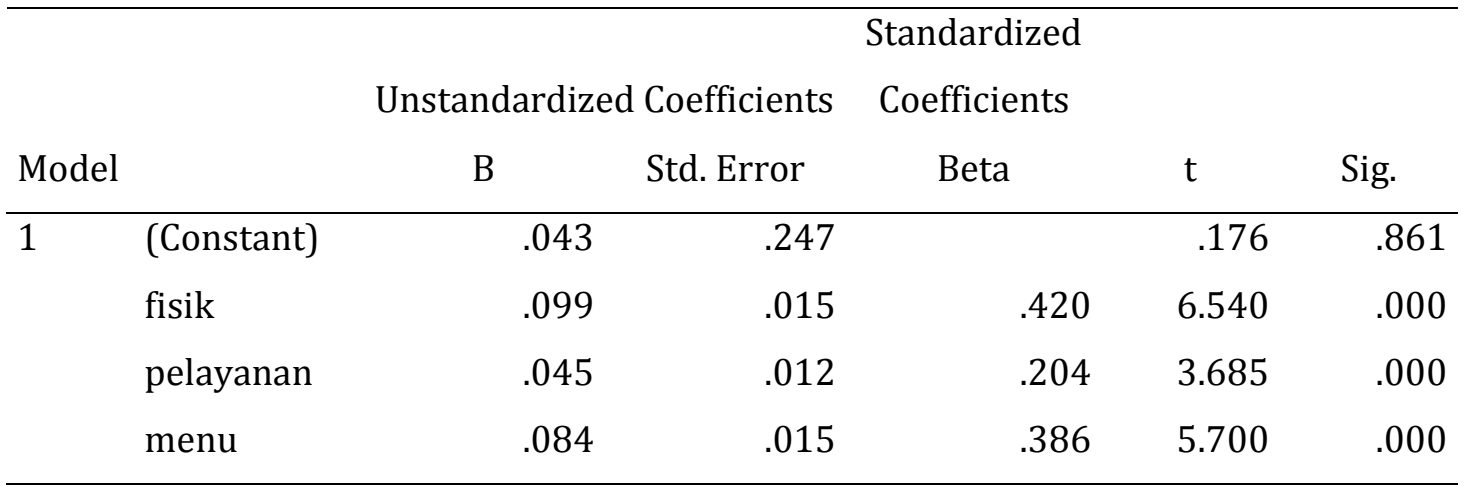

Dependent Variable: Kepuasan

Nilai koefisien atas variabel tampilan fisik sebesar 0.099, hal ini menandakan bahwa setiap terjadi peningkatan kualitas tampilan fisik maka akan mampu menaikkan tingkat kepuasan konsumen sebesar 9.9\%. Nilai koefisien atas variabel pelayanan sebesar 0.045 , hal ini menandakan bahwa setiap terjadi peningkatan pelayanan maka akan mampu menaikkan tingkat kepuasan konsumen sebesar 4.5\%. Nilai koefisien sebesar 0.084 pada variabel menu, rasa, dan harga menunjukkan bahwa setiap terjadi peningkatan variasi menu, rasa, dan harga akan mampu meningkatkan tingkat kepuasan konsumen sebesar 8.4\%.

\section{Tabel 2. Hasil Uji F}

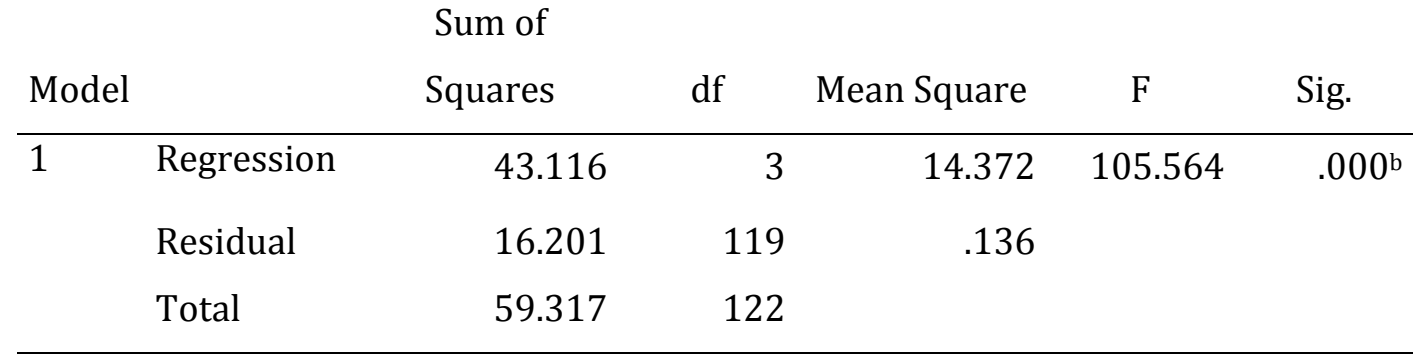

Dependent Variable: Kepuasan

Predictors: (Constant), menu1, pelayanan1, fisik1

Tabel 2. menunjukkan hasil uji F, uji F ialah suatu uji yang dipergunakan untuk melihat seberapa besar pengaruh variabel bebas dalam memengaruhi 
variabel terikat. Hasil pada Tabel 2. menunjukkan nilai F-hitung yang lebih besar daripada F-tabel, hal ini menunjukkan bahwa seluruh variabel bebas (tampilan fisik, pelayanan, serta menu, rasa, dan harga) secara bersama-sama memengaruhi variabel tingkat kepuasan konsumen.

Tabel 3. menunjukkan hasil atas koefisien determinasi. Secara umum, nilai koefisien korelasi menunjukkan nilai 0.853 . Hal ini menunjukkan bahwa terjadi hubungan yang erat antara variabel bebas dan variabel terikat. Kemudian nilai koefisien adjusted R-square sebesar 0.72 menunjukkan bahwa variabel bebas yang ada telah mampu menjelaskan tingkat kepuasan konsumen sebesar 72\%, sisanya 28\% dijelaskan oleh variabel lain di luar model.

Tabel 3. Koefisien Determinasi

\begin{tabular}{llrrr}
\hline Model & R & R Square & \multicolumn{1}{c}{ Adjusted R Square } & \multicolumn{2}{c}{ Std. Error of the Estimate } \\
\hline 1 & $.853^{\mathrm{a}}$ & .727 & .720 & .36898 \\
\hline
\end{tabular}

Predictors: (Constant), menu1, pelayanan1, fisik1

Tabel 4. menunjukkan hasil regresi logistik. Penggunaan regresi logit ialah untuk melihat seberapa besar pengaruh variabel tampilan fisik, pelayanan, serta menu, rasa dan harga dalam memengaruhi tingkat keputusan pembelian dari civitas akademika. Berdasarkan hasil empiris yang sudah dilakukan menunjukkan bahwa variabel yang memengaruhi keputusan pembelian apakah di dalam lingkungan kampus atau di luar lingkungan kampus hanyalah faktor menu, rasa, dan harga. Sedangkan variabel lain seperti tampilan fisik dan pelayanan tidak memengaruhi keputusan pembelian dari civitas akademika UIN Syarif Hidayatullah Jakarta.

Tabel 4. Hasil Regresi Logistik

\begin{tabular}{llrrrrrr}
\hline & & B & \multicolumn{1}{c}{ S.E. } & Wald & df & \multicolumn{1}{c}{ Sig. } & \multicolumn{1}{c}{$\operatorname{Exp(B)}$} \\
\hline Step 1a & fisik & .023 & .091 & .064 & 1 & .801 & 1.023 \\
& pelayanan & -.059 & .074 & .634 & 1 & .426 & .943 \\
& menu & -.251 & .091 & 7.640 & 1 & .006 & .778 \\
& Constant & 4.725 & 1.595 & 8.780 & 1 & .003 & 112.754 \\
\hline
\end{tabular}

Variable(s) entered on step 1: fisik1, pelayanan1, menu1.

Nilai koefisien yang negatif pada variabel menu, rasa, dan harga menunjukkan bahwa faktor yang memengaruhi keputusan pembelian civitas akademika untuk membeli makanan dan minuman di dalam lingkungan kampus 
ialah faktor variasi menu, higienitas, porsi, rasa, dan harga. Sedangkan faktor tampilan fisik dan pelayanan tidak memengaruhi keputusan pembelian apakah di dalam lingkungan kampus ataukah di luar kampus.

Hasil empiris yang didapat pada penelitian ini menunjukkan bahwa tingkat kepuasan konsumen atas layanan kantin dipengaruhi oleh tampilan fisik dari kantin, pelayanan, serta menu, rasa, dan harga. Hasil ini sesuai dengan temuan Rinawati (2008), dimana hasil penelitian menunjukkan bahwa tingkat kepuasan konsumen terhadap kualitas produk dengan tingkat kesesuaian 82,34\%, sedangkan tingkat kepuasan terhadap layanan produk dengan tingkat kesesuaian 85,11\% dan dapat disimpulkan bahwa kualitas produk dan layanan restoran student corner sangat memuaskan.

Wulansari, Setiawan, dan Sinaga (2013) telah melakukan penelitian yang bertujuan untuk mengetahui penyelenggaraan makanan dan tingkat kepuasan konsumen di Kantin Zea Mays Institut Pertanian Bogor. Berdasarkan hasil analisis Importance Performance Analysis (IPA) diketahui bahwa atribut yang dirasakan paling penting adalah keamanan dan kebersihan produk sedangkan atribut tingkat kinerja yang paling tinggi skornya adalah kebersihan tempat makan. Lebih dari separuh subjek masih memerhatikan kandungan gizi menu (50.5\%). Berdasarkan Customer Satisfaction Index (CSI) diperoleh nilai kepuasan sebesar 69.3 (puas).

Ronitawati dan Simangunsong (2016) melakukan penelitian yang bertujuan untuk menganalisis kualitas makanan dan kualitas pelayanan terhadap tingkat kepuasan konsumen di kantin Universitas Esa Unggul. Hasil penelitian menunjukkan bahwa ada hubungan antara kualitas makanan dan kualitas pelayanan terhadap tingkat kepuasan konsumen. Berdasarkan hasil analisa regresi logistik bahwa kualitas pelayanan merupakan faktor yang paling dominan yang mempengaruhi tingkat kepuasan konsumen.

Cahyo (2015) melakukan penelitian yang bertujuan untuk meningkatkan kepuasan konsumen dengan melakukan penilaian tingkat kepuasan konsumen terhadap kualitas pelayanan serta menentukan atribut dimensi kualitas pelayanan yang menjadi prioritas dalam perbaikan kualitas pelayanan pada The Hill's Dining 
Restaurant. Atribut dimensi kualitas pelayanan yang menjadi prioritas perbaikan yaitu Atribut Emphaty 2 kesenjangan (gap)(- 1,33) kapabilitas sigma $(1,82)$, Atribut Tangible 5 kesenjangan (gap)(-1,23) kapabilitas sigma $(1,82)$, Atribut Assurance 6 kesenjangan (gap)(-1,23) kapabilitas sigma (1,85), Atribut Tangible 2 kesenjangan (gap)(-1,33) kapabilitas sigma (1,88), Atribut Responsivenes 5 kesenjangan (gap)(-1,30) kapabilitas sigma (1,89), Atribut Assurance 5 kesenjangan (gap)(-0,86) kapabilitas sigma $(2,14)$ dan Atribut Emphaty 4 kesenjangan (gap)(-0,73) kapabilitas sigma $(2,14)$. Berdasarkan pengukuran atribut dimensi kualitas pelayanan tersebut maka diperlukan perbaikan atau penanganan lebih lanjut guna meningkatkan kepuasan konsumen.

Kurniawati dan Budiadi (2015) berusaha menjelaskan pengaruh kualitas layanan terhadap kepusan konsumen pada Cafetaria Srikandi Fakultas Ekonomi Universitas Negeri Surabaya baik secara simultan maupun parsial. Hasil penelitian menunjukkan bahwa terdapat pengaruh secara simultan antara kualitas layanan terhadap kepuasan konsumen dan secara parsial hanya empat variabel yang berpengaruh yaitu tangible, responsiveness, assurance dan emphaty. Sedangkan reliability tidak berpengaruh terhadap kepuasan konsumen. Adapun hasil penelitian menunjukkan bahwa variabel emphaty adalah variabel yang paling dominan berpengaruh terhadap kepuasan konsumen pada Cafetaria Srikandi Fakultas Ekonomi Universitas Negeri Surabaya.

Kustiyoasih, Adriani, dan Nindya (2016) melakukan penelitian yang bertujuan untuk menyelenggarakan makanan dan kepuasan konsumen di kantin Rumah Sakit Universitas Airlangga. Hasil penelitian menunjukkan jumlah responden yang menyatakan puas adalah 29 responden (58\%), sedangkan yang menyatakan tidak puas adalah 21 responden (42\%). Responden menyatakan puas pada beberapa indikator kepuasan antara lain indikator cita rasa, penampilan makanan, besar porsi, dan ketepatan waktu, namun responden tidak puas pada indikator kebersihan pada kantin. Disimpulkan bahwa kebersihan kantin yang terjaga dapat berpengaruh terhadap kepuasan konsumen, sehingga indikator kebersihan tersebut perlu ditingkatkan agar pengunjung lebih nyaman dan aman untuk membeli. 
Hasil penelitian sesuai dengan teori yang diajukan oleh Kotler (2000), dimana terdapat lima faktor dominan penentu kualitas jasa yaitu: (1) Tangible (berwujud). Jasa yang dapat dilihat oleh konsumen berupa penampilan fasilitas fisik, peralatan, teknologi dan berbagai materi komunikasi yang baik, menarik dan terawat; (2) Empathy. Kesediaan karyawan dan pengusaha untuk lebih peduli memberikan perhatian secara pribadi kepada langganan. Setiap lapisan karyawan dari level manajemen atas (top management) sampai dengan level terbawah (staf) harus memberikan pelayanan terbaik kepada konsumen. Setiap elemen dalam perusahaan mempunyai kewajiban memberikan pelayanan yang terbaik kepada konsumen; (3) Responsiveness (cepat tanggap). Kemauan dari karyawan dan pengusaha untuk membantu pelanggan dan memberikan jasa dengan cepat serta mendengar dan mengatasi keluhan dari konsumen. Setiap keluhan dari konsumen harus langsung diberikan umpan balik, untuk mencegah ketidakpuasan konsumen; (4) Reliabitily (keandalan). Kemampuan untuk memberikan jasa sesuai dengan yang dijanjikan, terpercaya, akurat, dan konsisten. Suatu perusahaan yang mampu memberikan pelayanan sesuai dengan apa yang telah dijanjikan melalui promosi akan memberikan kepuasan tersendiri kepada konsumen.; (5) Assurance (kepastian). Berupa kemampuan karyawan untuk menimbulkan keyakinan dan kepercayaan terhadap janji yang telah dikemukakan kepada konsumen. Karyawan harus mampu menunjukkan kepada konsumen bahwasanya perusahaan mampu merealisasikan setiap janji yang telah ditawarkan kepada konsumen.

Program pelayanan kepada pelanggan dengan bertitik tolak dari konsep kepedulian kepada konsumen terus dikembangkan sedemikian rupa, sehingga sekarang ini program layanan telah menjadi salah satu alat utama dalam melaksanakan strategi pemasaran untuk memenangkan persaingan. Kepedulian kepada pelanggan dalam manajemen modern telah dikembangkan menjadi suatu pola layanan terbaik yang disebut sebagai pelayanan prima. Kata pelayanan prima dalam dunia bisnis biasa dikenal sebagai service excellence. 


\section{SIMPULAN}

Faktor yang memengaruhi tingkat kepuasan konsumen civitas akademika UIN Syarif Hidayatullah Jakarta terhadap kantin unit usaha Dharma Wanita UIN Syarif Hidayatullah Jakarta ialah tampilan fisik, pelayanan, serta menu, rasa, dan harga. Hasil ini diperlihatkan dari nilai uji t yang didapat, dimana seluruh variabel bebas yaitu variabel tampilan fisik, variabel pelayanan, serta variabel menu, rasa, dan harga secara parsial memengaruhi tingkat kepuasan konsumen. Kemudian hasil uji F menunjukkan bahwa seluruh variabel bebas secara simultan memengaruhi tingkat kepuasan konsumen. Selain itu, nilai adjusted $\mathrm{R}$ square sebesar 0.72 menunjukkan bahwa $72 \%$ variabel yang ada telah mampu menjelaskan tingkat kepuasan konsumen. Sedangkan sisanya 28\% dijelaskan oleh variabel lain di luar model yang ada.

Faktor yang berpengaruh terhadap keputusan pembelian civitas akademik UIN Syarif Hidayatullah Jakarta apakah lebih memilih di dalam lingkungan kampus atau di luar lingkungan kampus hanya faktor menu, rasa, dan harga. Sedangkan faktor lainnya seperti tampilan fisik dan pelayanan tidak berpengaruh terhadap keputusan pembelian. Konsumen lebih memilih untuk membeli di kantin lingkungan kampus didasarkan pada menu, rasa, dan harga.

Secara umum, tingkat kepuasan konsumen terhadap kantin unit usaha Dharma Wanita UIN Syarif Hidayatullah Jakarta ialah sudah cukup baik. Meskipun masih dibutuhkan beberapa pembenahan dan perbaikan, serta peningkatan kualitas layanan kantin unit usaha Dharma Wanita UIN Syarif Hidayatullah Jakarta.

\section{PUSTAKA ACUAN}

Alma, Buchari. Manajemen Pemasaran dan Pemasaran Jasa. Bandung: Alfabeta. 2004

Amrin, Abdullah. Strategi Pemasaran Asuransi Syariah. Jakarta: Grasindo. 2007

Antonio, M. Syafii. Bank Syariah: Teori dan Praktik. Jakarta: Gema Insani Press. 2001.

Arifin, Zainul. Dasar-dasar Manajemen Bank Syariah. Jakarta: Alfabet. 2006 
Aritonang, Lerfin R. Kepuasan Pelanggan. Jakarta: PT Gramedia Pustaka Utama. 2005.

Barata, Atep Adya. Dasar-dasar Pelayanan Prima. Jakarta: Elex Media Komputindo. 2003.

Cahyo, Feri Nur. Peningkatan Kepuasan Pelayanan Terhadap Kualitas Pelayanan The Hill's Dining Restaurant Menggunakan Pendekatan Service Quality dan Six Sigma. $2015 . \quad$ Diakses pada http://eprints.dinus.ac.id/17507/1/jurnal_16023.pdf

Candra, Gregorius. Strategi Program Pemasaran. Yogyakarta: Andi Offset. 2002.

Engel, James F, et.al. Perilaku Konsumen, alih bahasa FX Budiyanto. Jakarta: Binarupa Aksara. 1992

Kasmir. Pemasaran Bank. Jakarta: Kencana. 2004

Kasmir. Etika Pemasaran Bank. Jakarta: Prenada Media. 2005

Kotler, Philip. Marketing Management, The Millennium Edition. New Jersey: Prentice Hall. 2000

Kotler, Philip dan AB Susanto. Manajemen Pemasaran di Indonesia. Jakarta: Salemba Empat. 2000

Kotler, Philip dan Kevin Lane. Manajemen Pemasaran, alih bahasa Benyamin Molan. Jakarta: Indeks. 2007

Kotler, Philip dan Waldemar Pfoerstsch. B2B Brand Management, alih bahasa Natalia Ruth S. Jakarta: Bhuana Ilmu Populer. 2008.

Kurniawati, Rahayu Dwi \& Setiyo Budiadi. Pengaruh Kualitas Layanan Terhadap Kepuasan Konsumen pada Cafetaria Srikandi Fakultas Ekonomi Universitas Negeri Surabaya. 2016. Diakses pada http:// jurnalmahasiswa.unesa.ac.id/article/10987/54/article.pdf

Kustiyoasih, Mustika Putri., Merryana Adriani \& Triska Susila Nindya. Penyelenggaraan Makanan dan Kepuasan Konsumen di Kantin Lantai 2 Rumah Sakit Universitas Airlangga Surabaya. Media Gizi Indonesia. Vol. 11 (1), 2016: 11-16.

Lupiyadi, Rambat. Manajemen Pemasaran Jasa. Jakarta: Salemba Empat. 2001 
Rangkuti, Freddy. Measuring Customer Satisfaction. Jakarta: Gramedia. 2002

Rinawati, Wika. Kepuasan Konsumen Terhadap Produk dan Layanan Makanan Restoran "Student Corner" Jurusan Pendidikan Teknik Boga dan Busana Fakultas Teknik UNY. JPTK. Vol. 17 (1), 2008: 119-138.

Ronitawati, Putri \& Desi W.T. Simangunsong. Analisis Kualitas Makanan dan Kualitas Pelayanan Terhadap Tingkat Kepuasan Konsumen Pada Penyelenggaraan Makanan di Kantin Universitas Esa Unggul.Nutrire. Vol. 8 (2), Oktober 2016: 65-70.

Schiffman, L.G. dan Kanuk L.L. Consumer Behavior. New York: Prentice Hall. 1997

Setiadi, J. Nugroho. Perilaku Konsumen: Konsep dan Implikasi untuk Strategi dan Penelitian Pemasaran. Jakarta: Prenada Media. 2003

Sugiarto, Endar. Psikologi Pelayanan dalam Industri Jasa. Jakarta: Gramedia. 1999

Susanto, AB, et.al. Value Marketing. Jakarta: Quantum Bisnis dan Manajemen. 2004

Stinnet, Bill. Think Like Your Customer, alih bahasa Kusnandar. Jakarta: Elex Media Komputindo. 2005

Sutopo dan Adi Suryanto. Pelayanan Prima. Jakarta: Lembaga Administrasi Negara. 2001.

Tjahjono, Fandy. Strategi Pemasaran. Yogyakarta: Andi Offset. 2002

Wulansari, Arnati., Budi Setiawan, \& Tiurma Sinaga. Penyelenggaraan Makanan dan Tingkat Kepuasan Konsumen di Kantin Zea Mays Institut Pertanian Bogor. Jurnal Gizi dan Makan. Vol. 8(2), 2013: 151-158.

Umar, Husen. Riset Pemasaran dan Perilaku Konsumen. Jakarta: JRBC. 2002 